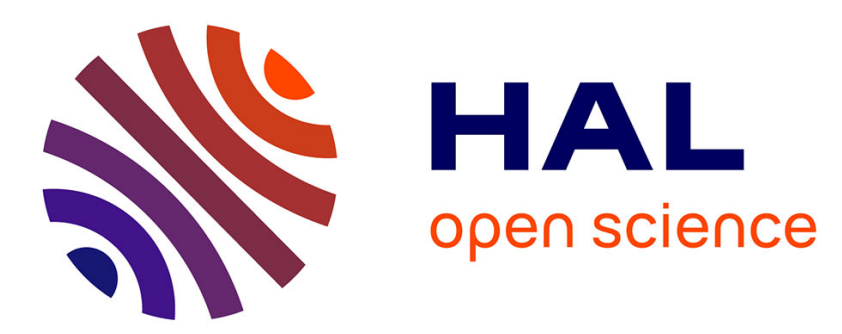

\title{
Collective Activity and Tutor Involvement in E-learning Environments for Language Teachers and Learners
}

François Mangenot, Elke Nissen

\section{To cite this version:}

François Mangenot, Elke Nissen. Collective Activity and Tutor Involvement in E-learning Environments for Language Teachers and Learners. Computer Assisted Language Instruction Consortium Journal, 2006, 23 (3). edutice-00001450

HAL Id: edutice-00001450

https://edutice.archives-ouvertes.fr/edutice-00001450

Submitted on 12 Apr 2006

HAL is a multi-disciplinary open access archive for the deposit and dissemination of scientific research documents, whether they are published or not. The documents may come from teaching and research institutions in France or abroad, or from public or private research centers.
L'archive ouverte pluridisciplinaire HAL, est destinée au dépôt et à la diffusion de documents scientifiques de niveau recherche, publiés ou non, émanant des établissements d'enseignement et de recherche français ou étrangers, des laboratoires publics ou privés. 


\title{
Collective Activity and Tutor Involvement in E-learning Environments for Language Teachers and Learners
}

\author{
François Mangenot \\ ELKe NisSen \\ Université Stendhal-Grenoble 3
}

\section{ABSTRACT}

Researchers investigating network-based language teaching (NBLT) seldom relate to computer-supported collaborative learning (CSCL), an important field in educational research which strongly stresses the value of group learning, adopting Vygotskian and Brunerian sociocultural views. As a result, the concept of collaboration is scarcely considered or discussed by NBLT researchers. However, choosing between collaborative- or noncollaborative-learning settings when designing a distance learning course has a strong influence on tutor involvement. This paper explores the issue, thus attempting to bridge the gap between NBLT and CSCL. It does so by qualitatively analyzing online interactions in several distance learning courses (collaborative and noncollaborative) and by examining these verbal exchanges in the light of collective activity, learners' social autonomy, and tutor role and involvement. The methodological approach is qualitative and consists in analyzing, a posteriori, online interactions between learners and tutors. After having defined the theoretical framework, the authors compare structures of online interaction in two preservice teacher courses, focusing on the role of the tutor and the issue of student autonomy. Finally, they examine more precisely some features of collaboration, analyzing tutor and student interactions in an online language course.

\section{KEYWORDS}

Computer-supported Collaborative Learning, Computer-mediated Communication, Distance Tutoring, Online Interactions, Group Autonomy.

\section{INTRODUCTION}

Whether called network-based language teaching (NBLT, see Warschauer \& Kern, 2000), telecollaboration (Belz, 2003a), or simply CMC (one of CALICO's special interest groups, see also Lamy \& Goodfellow, 1999), the use of ICT for fostering communication in foreign language learning has now become an impor- 
tant and acknowledged research branch within CALL. Strangely enough, though, researchers belonging to this branch seldom relate to computer-supported collaborative learning (CSCL); and, on the other hand, CSCL scholars seldom study noncollaborative online environments, and their research paradigm is often experimental. However, choosing between collaborative- or noncollaborative-learning settings when designing a distance learning course has a strong influence on tutor involvement. This paper explores this issue, thus attempting to bridge the gap between NBLT and CSCL. The corpus of verbal exchanges described here comes from three different courses, all of them carried out fully at a distance. Two of these (see section 2) are graduate courses for preservice teachers, one being based on collaboration and the other not. The third one (section 3) is a distance course of English as a second language meant as a collaborative environment.

We will first define our theoretical framework. We will then compare structures of online interaction in the two preservice teacher courses, focusing on the role of the tutor and the issue of student autonomy. Finally, we will examine more precisely some features of collaboration, analyzing tutor and students interactions in an online language course.

\section{THEORETICAL FRAMEWORK}

\section{Literature Review in NBLT}

In the introductory chapter of their book, Kern \& Warschauer $(2000$, p. 1) consider network-based language teaching (NBLT) as a form of CALL: "NBLT represents a new and different side of CALL, where human-to-human communication is the focus." The authors insist on communication, discourse communities, and sociocultural context; but they do not mention issues such as cooperation or collaboration. Addressing epistemological issues, Chapelle (2000, p. 218), in the last chapter of the same book, considers that "Network learning significantly expands the scope of CALL activities and, as a consequence, critical investigation of NBLT offers fresh perspectives on CALL's familiar themes." She further stresses the paradigm shift that NBLT research is likely to bring into second language acquisition (SLA) research.

Despite the impression one might gain that such classroom dynamics are ideal for language learning, their success may be difficult to document in more concrete terms. When the goals of an activity are to create conditions for interaction and reconfiguration of classroom culture, methods of evaluation must focus on interactions within the classroom culture-slipperier objectives than those involving development of grammatical competence, for example. (Chapelle, 2000, p. 219)

Three years later, a special issue of Language Learning \& Technologies (Belz, 2003a) was dedicated to the theme "telecollaboration." This expression might be misleading because it contains the word "collaboration," but Belz's (2003b) definition shows that this concept has not been fully investigated; she brings two new elements to Kern \& Warschauer's (2000) definition of NBLT: insistence upon 
the institutional and pedagogical aspects of telecollaboration and stress on the intercultural dimension of language learning. It is further interesting to note that the four articles of that special issue adopted a qualitative research design.

Kern, Ware, and Warschauer (2004) present a review of research on online language learning. This paper does not even mention CSCL: again, the word "telecollaboration" refers to any type of online communication. The authors identify and describe three salient themes in recent research: (a) studies which analyze the nature of interaction and try to infer how it impacts linguistic development, (b) research projects aiming at enriching learners' cultural and intercultural competence, and (c) ethnographic case studies exploring "literacy development and, in particular, the relationship of literacy to identity" (p. 253).

None of the authors quoted above differentiate the terms "communication," "collaboration," and "telecollaboration." They also overlook the role played by artifacts such as mail, chat, and forums used for mediating online interactions - a theme that is central in the field of CSCL.

\section{CSCL: An Emerging Paradigm? ${ }^{1}$}

The website of the last CSCL international Conference (Taiwan, May 2005) gives a very simple definition of this field "research findings related to learning in the context of collaborative activity and the exploration of how such learning might be augmented through technology" (http://www.cscl2005.org).

The first CSCL workshop took place in 1991, and the first international CSCL Conference was held 1995 in Bloomington, Indiana. From the beginning, there has been some ambiguity about the signification to be given to the second $\mathrm{C}$ of CSCL: does it stand for "cooperative, "collaborative," or "collective?" Johnson and Johnson (2004, pp. 785-811) argue that the words "cooperative" and "collaborative" are used as interchangeable terms; they prefer the expression "cooperative learning," which has been known in education since the beginning of the 20th century. However, many other authors distinguish between cooperation and collaboration, generally considering, along with Roschelle and Teasley (1995), that there is "a distinction between collaborative versus cooperative problem solving. Cooperative work is accomplished by the division of labor among participants, as an activity where each person is responsible for a portion of the problem solving," while collaboration may be seen "as the mutual engagement of participants in a coordinated effort to solve the problem together" (PAGE NUMBERS NEEDED)

We shall adopt George's (2001) proposal here to use the adjective "collective" as a hypernym of cooperative and collaborative. Such a proposal has two advantages - an empirical and an epistemological one. On the empirical side, it better corresponds to the way students accomplish tasks: cooperative and collaborative activities often alternate (George, 2001); students sometimes decide to divide up some subtasks or to complete other subtasks collaboratively (Nissen, 2003.) For this reason, it would be difficult and somehow artificial to restrict analysis to cases of collaboration. On the epistemological side, when the activity does not fall within the scope of collaborative learning but remains a group activity, it 
will be labeled "collective learning." The degree of interactiveness may then be an interesting variable to observe. Bullen (1997, p.40) considers that "interactive participation occurs when participants build on each other's contributions by making explicit or implicit references to each others' messages."

Regarding research methodologies, Dillenbourg, Baker, Blaye, and O'Malley (1996) state that there has been a shift from the "effect paradigm" ("is collaborative learning more efficient than learning alone?") to the "conditions paradigm" ("under which conditions is collaborative learning efficient?"). However, both approaches suffer from the fact that "the independent variables ... do not have simple effects on learning outcomes but interact with each other in a complex way" (p. 197). This has led to a third paradigm, called "the interaction paradigm" by the same authors. This third (and more recent) paradigm could much more easily allow cross-fertilization with the field of SLA (especially sociocultural SLA, see Ellis, 2003), where a lot of attention is given to interactions between peers (through the notion of "participatory structure", ${ }^{3}$ for example) and negotiation of meaning while students are accomplishing tasks.

\section{Issues of Tutor Involvement and Group Autonomy}

Abric (1996) defines group autonomy as the capacity of a group to manage itself on three levels: a socioaffective level (getting along with the others), a sociocognitive level (resolving problems together), and an organizational level (planning, monitoring, and evaluating work). As is the case for any other kind of autonomy, group autonomy (also called "social autonomy," Mangenot, 1996) has to be acquired (Barbot, 2000), especially in a technological context (Linard, 2003).

Several authors have dealt with the degree of autonomy required for collective learning activities. Henri and Lundgren-Cayrol (2001), for instance, out of their long teaching experience at the Télé-Université du Québec, show that cooperation is more structured (regarding activities) and more controlled (by the instructor) whereas collaboration requires more student autonomy: cooperative learning is thus a first step towards developing the social abilities and the ICT literacy required for collaboration. George (2001, p. 52) proposes the following table (our translation):

Table 1

Features of Cooperative and Collaborative Learning

\begin{tabular}{lll}
\hline \hline & Cooperative learning & Collaborative learning \\
\hline Structuring of activities & Strong & Weak \\
Teacher control & Strong & Weak \\
Learner roles & Assigned & Negotiated \\
Learners' social abilities & To be taught & Considered as a prerequisite \\
\hline
\end{tabular}

It may therefore be expected that students who have not had any prior practice in group learning will find it difficult to collaborate; working at a distance and using technological tools increases the difficulty. Asking students to collaborate if they 
are not prepared may thus result in the necessity for tutors to spend much more time in group management problems than they would have expected or wished to do.

\section{Research Questions and Methodology}

This study adopts Dillenbourg's suggestion "to stop looking for general effects of collaboration (e.g., in global developmental terms) and focus instead on more specific effects, paying attention to the more microgenetic features of the interaction" (Dillenbourg et al., 1996, p. 197). We will however extend their proposal to any form of collective learning. Several authors (e.g., Paulus, 2005; Peraya \& Dumont, 2003) point out that verbal interactions occur at three different levels: social, sociocognitive, and logistical. Two research questions will guide this exploratory study, anchored both in NBLT and CSCL.

1. What consequences, in terms of verbal interactions and hence of tutorial involvement, does the choice of a collaborative or a non-collaborative setting have?

2. How can tutors evaluate whether a collaborative setting actually leads to collaboration, and how can they enhance the latter?

Our methodological approach is qualitative and consists in analyzing, a posteriori, online interactions between learners and tutors in ecological (in the sense of "nonexperimental") contexts. As Dillenbourg (1999) suggests, "One should not talk about the effects of collaborative learning in general, but more specifically about the effects of particular categories of interactions" (p. 14). His framework remains nevertheless very general. Herring proposes a more detailed approach, which she calls "Computer-Mediated Discourse Analysis."

CMDA applies methods adapted from language-focused disciplines such as linguistics, communication, and rhetoric to the analysis of computer-mediated communication. It may be supplemented by surveys, interviews, ethnographic observation, or other methods; it may involve qualitative or quantitative analysis; but what defines CMDA at its core is the analysis of logs of verbal interaction (characters, words, utterances, messages, exchanges, threads, archives, etc.). In the broadest sense, any analysis of online behavior that is grounded in empirical, textual observations is computer-mediated discourse analysis. (Herring, 2004, p. 339)

Our approach entails carrying out a content analysis with a view toward eliciting some aspects of online behavior. The dimension of online behavior which will be investigated, in order to answer the research questions, is the management of collective activities. Language levels which might prove useful to be examined are the "participatory structure" (see section above on CSCL: An Emerging Paradigm) and speech acts related to task management.

\section{COLLECTIVE WORK IN TWO ONLINE PRESERVICE TEACHER COURSES}

In this section, we will compare the structure of online verbal interaction in col- 
laborative and noncollaborative settings, and analyze what these structures reveal about the tutor's role and involvement. Both online courses have similar objectives and are aimed at the same kind of audience. Both are preservice teacher distance courses designed for training teachers to better integrate ICT in language teaching and learning. First, we will present the courses, then, we will analyze the structure of verbal interaction in each of them. Finally, we will draw some conclusions about tutor involvement as related to the students' social autonomy in collaborative and in noncollaborative settings.

\section{Brief Presentation of the Two Courses}

The learning network for teachers and trainers (Learn-Nett) started in 1997 as a Socrates-EC-funded project with the aim of implementing a collaborative learning environment at the interuniversity level. The 6-credit university course prepares preservice teachers to use ICT for education and training. Groups of four or five students from different universities (and countries) are asked to experiment with ICT and its pedagogical uses. Each group (there are up to 20 groups) chooses a particular theme and is coached by a tutor. The course objectives focus on the collaborative process, the product of collaborative work (which consists in designing or analyzing a specific use of ICT in school), and a reflective process about the experience.

The term Canufle means campus numérique français langue étrangère 'virtual campus for French as a foreign language,' a consortium of five universities (Université Stendhal-Grenoble 3, Ecole Normale Supérieure Lettres et Sciences humaines, Université Lumière-Lyon 2, Université de Franche-Comté. and Université de Bourgogne) offering a Masters' degree of French as a foreign language (maîtrise de français langue étrangère). This 60-credit degree was divided into several 3-credit and 6-credit courses; each of which was independent but adopted the same pedagogical model. The examples below are taken from a 6-credit course named "ICT for teaching and learning French as a foreign language" in which the objectives and students are similar to those of the Learn-Nett course.

\section{The Basic Interaction Structure of Canufle}

Within the pedagogical model of Canufle, online communication occurs through a single technological tool-discussion forums. This means that all pedagogical exchanges are asynchronous, written, and many-to-many, which helps build an online community (Develotte \& Mangenot, 2004). Each task has its own forum; instructions from the tutor may thus be considered as initiation moves, and students' contributions generated by these instructions may be seen as responses. Finally, students expect the tutor to give them feedback about their production. In general, this kind of interaction may seem similar to the IRF (initiation/response/ follow up) classroom interaction structure described by Sinclair and Coulthard (1975) and many others. Figure 1 presents an IRF interaction which occurred at the very beginning of the course. 
Figure 1

An Example of an IRF Interaction in Canufle (our translation)

Initiation (instruction)

How do you interpret the following mistake made by Microsoft Word gram mar check? When checking the sentence "Le jardinier les plante." [The gar dener plants them.], Word grammar check produces this message: "Subject/ Verb. Check this sentence. If gardener is subject of plant, there is a mistake with subject/verb agreement."

\section{Response (student)}

I think the mistake comes from the fact that Word doesn't make any differ ence between a noun and a verb when their form is identical. "Plante" may be either noun or verb. As "plante" is preceded by a pronoun, Word takes the pronoun to be a definite article.

Follow-up (tutor)

Yes, mistaking verb/noun and pronoun/article is one of the reasons for the erroneous analysis of Word. But not the only reason, I think ...

Nevertheless, comparison with traditional classroom exchanges should not be too quickly generalized because

1. Instructions call for open responses. There is no single correct answer to the question in Figure 1.

2. Contrary to what happens in a classroom, contributions following such an instruction are not limited. The instruction in Figure 1 generated an average of 10 messages.

3. Contribution length may strongly vary. In response to the instruction in Figure 1, students wrote from five lines up to two pages. In addition, they often tested many other sentences with the grammar checker.

4. As a result of the many-to-many communication mode, feedback may apply to several contributions, not only to a single contribution. The tutor then often tries to summarize his/her answers to different contributions. For instance, the first task of the course consists in expressing one's personal feelings about the difference between writing with pen and paper compared to writing with a word processor. This instruction gives rise to varied-often quite personal-student responses, and the tutor does not need to react to each of them. After a certain number of contributions has been published, the tutor just writes a message intending to show that he/ she is paying attention ("It is really interesting, reading your messages, to realize how differently everyone deals with technology! One could describe that as a kind of man/machine ecology ...").

5. Students may react to peers' contributions and even start more complex interaction modes, although they scarcely do so (it has never happened, for instance, with the two tasks mentioned here). 
Not all observed exchanges match the IRF structure, for instance, when direct exchanges between students occur. Mangenot (2003) shows that certain creative tasks are more likely to generate interactions between peers. In Develotte \& Mangenot (2004), two communicative events are presented: one in which a student intervenes in an apparently fruitless dialogue between another learner and the tutor to propose her help with regard to a difficult notion, and the other, in a course on intercultural matters, in which a debate emerges about Japanese civilization. In fact, debating is a very specific type of online activity because it focuses explicitly on interaction among peers.

\section{Learn-Nett}

In Learn-Nett, the pedagogical situation is as follows. Groups of four to five students are given the assignment to collaboratively design a pedagogical use of ICT within a 14-week time span; the product must be presented as a website. The students are preservice teachers. Pedagogical support is provided in the form of a tutor, and each of the 14 groups has its own tutor. Communication is based on a learning management system (LMS), called Claroline, which offers three tools: a threaded forum space, chatrooms, and a document library. Besides communication with the LMS, two general videoconferences are organized for the 70 students taking the course: one at the very beginning of the course and the second 6 weeks before the end.

The group whose interactions will be presented below has chosen the following theme (proposed among many others): "designing Internet-based writing tasks for native speakers or for nonnative speakers, adults or youths." The asynchronous exchanges that emerged in the forum space just after the initial videoconference (which took place on Thursday evening) are presented in Figure 2. All speech acts are social or logistical, which is normal at the beginning of a long-term collaborative task.

Figure 2

First Interactions in the Learn-Nett Course (our translation)

1) Friday February 6th, 10:54 - Student A (Swiss)

Hello B. [Belgian student]

I wanted to tell you the videoconference didn't enable us to see and hear you well. But I am glad to work on this project with you two and with my Swiss colleague.

2) Friday February 6th, 15:47 - Student B (Belgian)

Hello everybody!

This first message just intends to see how we could target our theme. I pro pose that each of us gathers some information, independently, and we could then arrange a direct online meeting for a discussion. I think the first step con sists in choosing whether we deal with French as a foreign language or with French as a mother tongue, and then selecting our audience. ... Indicate your availability for a chat and we'll choose a time which suits everybody. 
3) Friday February 6th, 16:13 - Student C (Swiss)

Hello everybody,

How are you keeping since our Thursday evening videoconference? What a pity the sound quality was poor; we couldn't hear the Belgian students very well. Regarding availability for a chat ...

4) Friday February 6th, $17 \mathrm{~h} 37$ - Student A (Swiss)

Hello everybody,

To answer B's message, I'd like to say it's a good way to start. My availability for a chat: ...

5) Saturday February 7th, 14:14 - Student B

After having talked to D. (how nice having direct communication!), here's our first chat meeting time: Monday at 12:15 precisely (till then, we may keep in touch through this forum). Have a nice time till then.

6) Saturday February 7th, 19:21- Student C

Good evening,

I took note of the meeting time for the chat. Unfortunately, I work in a canteen everyday except Wednesday around lunchtime. I'll see whether I can cancel my job, but it will be difficult. I'll be able to tell you only on Monday morn ing. I am sorry to complicate our first chat meeting. Have a nice evening.

7) Saturday February 7th, 20:58 - Student A

Monday chat is ok for me. I'm eager to communicate more or less in real time and to test this tool. Shall we organize ourselves in a special way (message colours, speech order)? The experience we had with chatting at our Univer sity was not very convincing, everybody wrote at the same time, we couldn't manage questions and answers.

8) Monday February 9th, 9:45 - Student C

hello,

I can make it despite my job. Let's meet later on the chat.

See you soon

9) Monday, February 9th, 10:51- Tutor

Hello A., B., C. and D.,

I am glad to work with you about conceiving writing tasks. ... Unfortunately, I was not able to participate in last Thursday's videoconference. ...

10) Monday, February 9th, 10h59 - Tutor,

Your planning a chat in order to decide on the first steps to adopt is a good idea: chatting is faster and more interactive than asynchronous messaging. If you don't mind, I'll come and watch your discussion, at about 12:30, for instance. As B. proposed, the first thing to do is to decide on the target group for the tasks you plan to design.

These interactions may be looked at from different perspectives. Apparently, the tutor's absence until Monday morning does not deter students from exchanging messages and organizing a first synchronous meeting; the tutor even volunteers to restrict his participation to observing (see message 10). The initiative is clearly taken by the students, including working methods (see message 2). They 
make a considerable effort, despite professional duties, to find a suitable time to hold a chat (see messages 6 and 8), to prevent the exclusion of a group member (see message 5), and to establish a good socioaffective working atmosphere (see messages 1, 3, and 5). Furthermore, it is interesting to note the days and times of connections: student A connects twice on Friday, students B and C once; while the Sunday break is respected, three students connect on Saturday; the fourth does not connect at all, but she is informed by her colleague from the same university (see message 5). They are all present for the Monday chat meeting. The structure of the interaction is not as regular as in Canufle, although the same tool is used (discussion forum). As in face-to-face interaction, certain messages contain reactive and initiative speech acts in either order. The degree of interactiveness may also be considered as high as that in Canufle. Regarding mediated communication and tool choice, an implicit hierarchy seems to exist. First, synchronous oral interaction appears to be best of all (see "how nice having a direct communication!"4); second, videoconferencing seems to be viewed as equivalent to a real encounter (see "How are you since Thursday evening?"); third, synchronous chatting is considered essential (nobody questions student B's proposal to organize a chat); finally, the discussion forum seems to come in last in terms of preference. Strangely enough, the latter finally turned out to be the most useful and most used tool.

\section{Implications Regarding Tutor Involvement}

This brief analysis of online interaction at the start of two different courses is sufficient to draw certain conclusions regarding tutor involvement in collaborative and in noncollaborative distance courses. These conclusions correspond to what several authors have written about the difference between cooperation and collaboration.

Canufle is strongly structured with respect to chronology, pedagogy, and even technology: in each subject, one or two tasks are assigned every month; students accomplish these tasks and receive feedback about their production; interaction between peers, although considered to be desirable, is not required (see Table 1 above). All exchanges occur through a single tool (forum). Experience shows that the many-to-many communication mode is sufficient for the students to feel part of a learning community (see Develotte \& Mangenot, 2004), but it is clear that no strong preexisting autonomy, social ability, or even ICT literacy is required for successfully following the course. The tutor's activity and involvement are rather predictable and repetitive (strong teacher control, see Table 1). The tutor does not depend much on the students' own activity and can easily manage large groups of up to 40 participants.

On the other hand, Learn-Nett presents quite a different picture. The course has an overall structure with two deadlines: an intermediate one (after 2 months) and a final one (after 3.5 months), but within this framework, students have a lot of freedom to manage the progression of their work (e.g., weak structuring of activities and negotiated learner roles, see Table 1). The students are divided into small groups of 4 to 5 and may use various technological tools in different ways. A 
simple analysis of different groups shows that the proportion of synchronous and asynchronous communication differs quite strongly. All these features demand a certain preexisting social, metacognitive, and technological autonomy, even if the purpose of the course is to increase this autonomy. The tutor's role and involvement may greatly differ according to several factors: level of autonomy of each participant, homogeneity of the group regarding autonomy, group dynamics on the socioaffective as well as on the sociocognitive level, and so forth. Deschryver (2003), who has been a Learn-Nett tutor for several years, confirms this unpredictability: "Regarding tutor's support, one may say that it differs depending on the group; some groups need a more directive support, while others have a more autonomous management" (p, 160, our translation) Thus, teacher control (see Table 1) may vary from strong to weak. It should be noted that the group whose initial exchanges are presented in Figure 2 turned out later to be a particularly autonomous one. This autonomy was probably due to several factors: the easy Internet access and good ICT literacy of three members out of four, the fact that participation in the Learn-Nett project was an option, the students' sense of accountability, and the fact that a member of the group (student B) turned out to be a "democratic leader" (Abric, 1998) who accomplished several tasks usually expected from the tutor (see Deschryver, 2003, for a similar case).

\section{DOES A COLLABORATIVE DESIGN ALWAYS LEAD TO COLLABORATIVE USAGE?}

One of the questions posed in this paper was to see whether designing a collaborative course systematically leads to collaboration between students and how the tutor may influence this dimension. We will answer this question through examples of interactions within a language-learning setting. First, we will describe the online course, then analyze the activity within the groups, and finally examine the interplay between collective learning, group autonomy, and tutor involvement.

\section{Presentation of the Language-learning Setting}

The licence professionnelle activités et techniques de communication (LPATC) program is an online degree program offered by the Université Louis Pasteur (Strasbourg). Students work online in the collaborative LMS apprentissage collaboratif à distance (Acolad). They are divided into small groups of at most 4 students. Three of these small groups have the same tutor and may sometimes work together as a larger group (at most 12 students). At the beginning of the year, a schedule is handed out to the students Each course lasts 3 weeks and includes two chat sessions during each of the first two weeks; in the third week, the students may work on their own or contact the tutor by email. Two or three courses in different subjects are taught in parallel.

A separate "classroom" is created for each course. One teacher writes course materials and designs a "learning situation" presenting a problem-solving task that has to be carried out by the groups during the course. Both (OF WHAT OR WHOM; THE TEACHER AND THE TUTOR?) are available in the learning set- 
ting, as well as the communication tools: chatrooms (every chat is saved automatically and can be consulted any time by every member of the group and the tutor), a shared workspace (any kind of document can be uploaded, accessed, and modified by the group members; older versions of the documents remain available), discussion forums (automatically linked to each new document), a function allowing emails to be sent to the whole group, and an Instant Messaging System (IMS) that also allows group members to see who else is online.

Regarding the English course, we will base our analysis on the synchronous interactions (via chats) generated by three groups (gp1, gp2, gp3) of 3 to 4 students (stud1, stud2, etc.); we will see below that these chat sessions are central to the decision making process. The task consists of writing an essay based on several documents (online videos and texts) dealing with a topic globally related to the online degree (e.g., internet ethics or broadband Internet). After having consulted these documents, the students are asked to brainstorm and agree on the main ideas, plan an outline for their essay together-including an introduction and a conclusion, compose the different parts, and finally correct each other's drafts, paying attention to the coherence of the whole essay. As a support for their task, four writing aids are available in their virtual classroom:

1. an explanation concerning the appropriate structure for an essay and some methodological hints,

2. advice on how to avoid frequent mistakes,

3. an English-French glossary, and

4. links to grammar, vocabulary, listening and reading exercises, and online dictionaries.

\section{Cooperation or Collaboration?}

The use of communication tools is similar in all the courses in the degree program and in this LMS. Usually, the students take note of the given task and decide on who will do what to accomplish the task. They work individually on their part of the task, put their draft on the "shelf" (shared space), alert the others by email, and then ask the others for comments during the regular chat sessions. Contrary to what was observed in Canufle and Learn-Nett, the discussion forums remain unemployed by Acolad users. The reason is probably that, in this LMS, forums are always linked to a shared document; hence, there are too many forums. In this context, we can note an influence of the technological setup on the frequency of the use of communication tools. The consequence is that decisions are almost always made through chats. These chats are supervised by the tutor of the three groups who, for economic reasons, has to participate in three chat sessions at the same time, making it difficult for the tutor to participate actively in each of them. Students also organize supplementary chats without any tutoring in order to speed up group work.

As stated above, the students are asked to negotiate every step of the task, although they may write parts of the essay separately. We will give some examples of such decision-making below. However, most of the time, a consensus regard- 
ing decisions is easily and quickly achieved. Proposals are not really discussed or confronted, but simply accepted, as in Excerpt 1.

\section{Excerpt 1}

13:02:56 gp2_stud4 first part What is internet / Second part what is Nar rowband and Broadband ?/ Third part : Narrowband vs Broadband

13:03:07 gp2_stud4 What do you think of that?

13:03:24 gp2_stud1 ...

13:03:27 gp2_stud3 ok

13:03:29 gp2_stud3 good

13:03:33 gp2_stud2 it's good

13:03:40 gp2_stud3 ;)

13:04:15 gp2_stud4 good, then just need to develop now ;*))

Everything seems to indicate that the group members want to go on with the production in order to finish it in time. Although negotiation is considered as a priority by the course designers (who claim a CSCL and a sociocultural SLA approach), it is time consuming and often avoided by these students who spend an entire year working in small groups in the same LMS. Short-term efficiency -in the sense of completing the task - seems to be the major objective. The students are not eager to find new challenges (e.g., finding a new solution together), instead, they rely on their prior knowledge and skills. This collective behavior is closer to what Pléty (1998) calls a "production group," (concerned with the effectiveness of production) than to a "learning group" (concerned with the effectiveness of learning).

Thus, interactions between students mostly focus on deadlines: who does what and which communication tool will be used, as shown in Except 2.

\section{Excerpt 2}

13:07:01 gp3_stud1 i propose we work on your document gp3_stud2?

13:07:12 gp3_stud2 ok no problem

13:07:19 gp3_stud1 on asynchrone

13:07:22 gp3_stud1 ok

13:07:34 gp3_stud1 so i upload it now

13:08:04 gp3_stud2 yes and we 11 try to us before next week

13:08:12 gp3_stud2 see

13:08:31 gp3_stud2 :)

This brief overview of the typical interaction mode in the English course shows that these students cooperate at least as much as they collaborate. If we reconsider Table 1, we can propose the following analysis:

1. The task is strongly structured (which corresponds more to a cooperative feature).

2. The tutor gives regular feedback but only after the group has agreed on their (intermediate or final) task fulfillment; tutor control falls therefore 
somewhere between weak (as in collaboration) and strong (as in cooperation).

3. The students mostly negotiate their role in task completion (collaborative feature).

4. However, they do not show much commitment in overcoming cognitive problems: they simply avoid sociocognitive conflict by accepting almost all their partners' proposals (cooperative feature).

\section{Group Autonomy and Tutor Involvement}

It is important to note that the LPATC students are already accustomed to collective learning when they start their English course: they have already had several months' attendance in other courses with a similar design. This may be an explanation for certain dimensions of group autonomy.

\section{Autonomous Decisions}

Groups do not always require the tutor's help to make decisions. They often manage on their own and spontaneously decide on a meeting date and hour to carry on with their task between chat sessions with their tutor. However, their decision making does not only concern organization of the group work, it can also concern methodological aspects of the problem solving itself. They may react when a group member makes a proposition that is not consistent with the course instructions. In the following quote, a student wants to sum up separately each of the given documents (videos and texts), but another student reminds him that, instead, he is supposed to find the main ideas of all the documents as a first step of writing their essay.

Excerpt 3

13:16:53 gp2_stud2 (I will) try to wrtite a text for the others document

13:18:38 gp2_stud1 i think you musn't write a text for the others documents, but write a part it's not a sum up but a synthesis

13:19:09 gp2_stud1 we need text just for content

13:20:14 gp2_stud1 you can put your sentence in part who reflect ideas of texts

A group member may also ask the group to reconsider its task-solving method, giving advice that would lead the group to a better accomplishment of the task.

Excerpt 4

13:12:56gp3_stud3

13:13:24 gp3_stud1

13:13:50 gp3_stud3

13:14:21 gp3_stud3

13:14:32 gp3_stud1

13:15:05 gp3_stud3 must one add the caracteristiques ones?

?

data

ex : 8000000 bits per second

yes i think

faut pas trop tomber dans le détail !!!! [Don’t go too much into detail !!!!] 
Sometimes, a group leader suggests how to proceed with the task, playing almost a tutor role, and may then be encouraged to play this role by the tutor himself/herself.

\section{Excerpt 5}

13:29:48 gp1_stud1 i finished correcting the mistakes i spoted

13:30:04 gp1_stud1 maybe you could re-read the whole document

13:30:18 gp1_stud1 to see if you could improve your part

13:30:29 gp1_stud1 to make the whole thing more coherent ?

13:30:45 gp1_stud1 all of us i mean

13:30:46 tutor good idea

These examples show that some group members are able to give methodological advice to the group or to criticize ideas when those ideas do not appear to ensure task completion. However, such advice is never followed by any negotiation. As stated earlier, the groups rarely engage in discussions on a sociocognitive level. This means that one of the three levels of group autonomy is quite low. Nevertheless, the socioaffective level and the organizational level are high; the group members seem to get along with each other very well, even if this is achieved by avoiding confrontation. The group members are also good at distributing tasks and organizing deadlines to accomplish the task on time. One may state that the students show strong autonomy regarding two out of the three criteria we set above.

\section{Tutor Support}

The tutor's role consists in helping the groups both on the organizational and the sociocognitive levels. Although working with students who are familiar with collective learning, the tutor provides important support in some situations.

1. The tutor reminds students about the schedule of the course.

\section{Excerpt 6}

13:19:28 tutor sorry to interrupt

13:19:30 tutor you will have to post the plan before the 27th noon after discussing it in your group

2. The tutor asks students to continue with their task instead of talking about other topics.

\section{Excerpt 7}

12:22:51 gp1_stud1 you got the virus before it got you ?

12:22:54 gp1_stud3 no panic it is an old virus

12:23:03 gp1_stud3 W32.pinfi

12:23:12 gp1_stud1 got it by mail ?

12:23:20 gp1_stud3 yes

12:23:31 gp1_stud3 it attacks word documents

12:23:57 tutor get back to work ... 
3. The tutor gives methodological advice to students, in a rather patronizing mode, when she feels that they are unlikely to change their approach and improve.

\section{Excerpt 8}

12:31:55 tutor gp1_stud3, you are not supposed to write the intro duction in French and then translate it!

4. The tutor gives feedback after each step during the writing of the essay.

5. The tutor asks the groups to reconsider their drafts of their essay and to make modifications.

However, the presence of a tutor can also have a negative effect. Knowing that the tutor will assess their writing, some of the students refer to the tutor as often as possible and ask her for acknowledgement instead of trying to discuss matters within the group. For instance, the following interaction shows a student who focuses on getting the tutor's opinion instead of finding a solution that satisfies the group:

\section{Excerpt 9}

12:55:34 gp2_stud3 Teacher please have you seen the intro and part one is everything ok

12:55:40 gp2_stud3 there is no remarks?

12:57:17 gp2_stud3 for that we can make the part $2 \& 3$ and for that I can fin ish the conclusion

In such cases, it is up to the tutor to reorient the students and invite them to rely more on the group. In groups that sometimes tend to save time by too easily accepting each other's proposals, the tutor also has to remind them that discussion and negotiation are part of the learning process.

Although it is part of the pedagogical design of the course that tutors may intervene in this way, the tutor actually does not often encourage students to negotiate more. Because the tutor has to monitor three chats simultaneously, it is particularly difficult for her to notice when discussions fail to develop.

All in all, it is worth noting that the strong group autonomy on the organizational and socioaffective levels allows a lower tutor commitment, which is reflected, for instance, in the fact that the tutor is able to follow several groups at the same time.

\section{Influence of the Students' Language Level}

Another question could be how far group autonomy is related to the students' language level. The groups are assembled according to the students' language level to avoid students relying on one stronger group member. Group 1 is the one with the highest English level (B1 to C1 on the scale of the European Framework), and group 2 and 3 have approximately the same (lower) language level (A1+ to B1). ${ }^{5}$

At the beginning of the course, even in the group with the highest language level, a student asks to communicate in French during the first meeting despite the 
rule to communicate in English. Only when someone is really unable to express something in English, is he or she allowed to write in French. This rule is rapidly accepted by all the groups, regardless of their level of language. However, having to negotiate task organization, text meaning, and language accuracy in a foreign language imposes a high cognitive demand on the students. Some of the negotiation levels appear to be easier. The examples given above showed that autonomous group decisions are made in each of the groups, even in those with a lower language level: social and organizational abilities do not seem to be reduced when interacting in English. On the contrary, students consider correcting each other as something out of their reach.

\section{Excerpt 10}

$12: 37: 28$ tutor is it important to correct each other?

12:37:58 gp2_stud3 well yes sometimes

12:38:02 gp2_stud1 yes but for correct you can find the mistakes

12:38:27 gp2_stud1 and i'm too bad in english for correcting the other

It should be added that group dynamics in group 1 represent a particular case. It may be due to the higher language level of its members but also to the behavior of one student (gp1_stud1). It is quickly noticeable that the group insists several times on its good management, which is also confirmed by the tutor.

Excerpt 11

12:55:40 gp1_stud2 I think that our group functions well

12:55:54 tutor I think so too

However, maybe reality is not so positive because not all of the members regularly participate in the chat sessions; two of them are sometimes absent. One student (gp1_stud1, a male student) wants to accomplish the task within the deadlines, and he points out the lack of motivation of other students, a problem he has apparently experienced in previous courses.

Excerpt 12

12:56:42 gp1_stud1 i'll do the 3 main ideas, i'll leave introduction and conclusion to you, ok?

12:57:15 gp1_stud1 unless you want to rely on pleople who aren't there ?

13:00:00 gp1_stud2 gp1_stud3 and gp1_stud4 [will do] part 3 and intro/conclu

13:00:35 gp1_stud1 ok, i'll prepare something for their parts too

13:00:44 gp1_stud1 just in case they don't do it

13:00:54 gp1_stud1 i'm getting used to this now

13:01:41 gp1_stud2 no gp1_stud1

13:01:56 gp1_stud1 you wanna bet?

13:02:03 gp1_stud2 it is a team work

He suggests completing the others' parts, without caring about the extra work it represents for him. In these moments, as well as during discussions on methodol- 
ogy for problem solving, he is the one who makes the propositions. He turns out to be the leader of the group, although he is focused more on the accomplishment of the task than on a well balanced teamwork. He also has the best language level. These two factors are probably linked.

To sum up, a higher language level seems to ease task accomplishment as well as group leadership, but even students with a lower language level are able to interact and to complete a complex task in the L2 together.

\section{CONCLUSIONS}

The three distance learning settings we have studied are very different, both in their audience and in their pedagogical design. Nevertheless, our analysis of microgenetic features of the interaction allows us to come to two conclusive findings, one regarding collective design correlated to verbal interactions and tutor involvement, and the other suggesting ways for tutors to increase collaboration.

Concerning collective design and verbal interactions in distance online courses, the greatest difference between the three courses concerns the logistical dimension: there is no need for logistical interactions in Canufle because tasks are individually fulfilled. In LPATC, students tend to choose the most time-saving mode for task completion: chat sessions are mainly used for division of work and for (fast) decision making. In Learn-Nett, the task is more vaguely defined, and the course spans a much longer period of time with no fixed chat sessions and a single intermediate deadline, which induces a great amount of logistical interactions. Concerning tutor involvement, it seems that a collaborative setting requires more student autonomy, Learn-Nett being the most demanding course in this aspect. Tutor involvement is then difficult to predict, depending on the ability of the group to manage itself more or less autonomously. The LPATC students show good autonomy at the social and logistical levels, which allows, for instance, the tutor to follow three groups simultaneously during the chats, but they seldom collaborate at the cognitive level (which would imply more negotiation of meaning, considered a central component in SLA); they focus generally more on timely task completion than negotiation. The tutor rarely intervenes on organizational and social dimensions and concentrates more on linguistic aspects. Tutor involvement in Canufle is rather predictable and not very high, given the fact that groups are large. However, it is worth noting that, due to the content-centered character of the courses, greater competence in the subject is required: Canufle tutors are always university teachers. In any case, Learn-Nett is more costly than Canufle since it requires a tutor for each group of 4 or 5 students. The only way to reduce these costs would be to presuppose strong student autonomy and, therefore, to propose a more loosely defined tutor support, but it is easy to imagine how hazardous such a choice might turn out to be.

Regarding some ways to enhance collaboration at a sociocognitive level (i.e., negotiation of meaning), we may note that LPATC course guidelines insist on the necessity of interaction between students: discussing their interpretation of the documents, exchanging their ideas for the essay outline, and checking the coherence between drafts. However, just insisting on these aspects was clearly not 
enough. Indeed, we showed that there was little negotiation of meaning. Stimulating the students to accept developing new skills instead of using those they already have might be seen as an important part of the tutor's role, but this would probably entail both more commitment (more time to dedicate to each group) and better training.

\section{NOTES}

${ }^{1}$ The characterization of CSCL we use in this paper was proposed by Koschmann (1996).

${ }^{2}$ CSCL also considers the case of learners collaborating in front of the same computer or through an intranet, but here we restrict our topic to distance-learning settings.

3 "The participatory structure of a lesson refers to the procedures that govern how the teacher's and students' contributions to the performance of the task are organized" (Ellis, 2003, p. 263).

${ }^{4}$ The interaction does not show whether the two Belgian students communicated faceto-face or by phone, but we know that one of them did not have an Internet connection at home.

${ }^{5}$ See the Common European Framework of Reference for Languages (http://culture2.coe. int/portfolio//documents/0521803136txt.pdf).

\section{REFERENCES}

Abric, J.-C. (1996). Psychologie de la communication. Paris: Armand Colin.

Barbot, M.-J. (2000). Les Auto-apprentissages. Paris: Clé International.

Belz, J. A. (Ed.). (2003a). Telecollaboration [Special Issue]. Language Learning \& Technology, 7 (2). Retrieved February 7, 2006, from http://llt.msu.edu/vol7num2/de fault.html

Belz, J. A. (2003b). Welcome to the special issue. Language Learning \& Technology, 7 (2), 2-5. Retrieved February 7, 2006, from http://1t.msu.edu/vol7num2/speced.html

Bullen, M. (1997). A case study of participation and critical thinking in a university-level course delivered by computer conferencing. Unpublished doctoral dissertation, University of British Columbia, Vancouver, British Columbia, Canada.

Chapelle, C. A. (2000). Is networked-based learning CALL? In M. Warschauer \& R. Kern (Eds.), Network-based language teaching: Concepts and practice (pp. 204-228). Cambridge: Cambridge University Press.

Deschryver, N. (2003). Le rôle du tutorat. In B. Charlier \& P. Peraya (Eds.) Technologie et innovation en pédagogie (pp. 149-162). Bruxelles: De Boeck université.

Develotte, C., \& Mangenot, F. (2004). Tutorat et communauté dans un Campus numérique non collaboratif. Distances et savoirs, 2 (2-3), 309-333.

Dillenbourg, P., Baker, M., Blaye, A., \& O’Malley, C. (1996). The evolution of research on collaborative learning. In E. Spada \& P. Reiman (Eds.), Learning in humans and machine: Towards an interdisciplinary learning science (pp. 189-211). Oxford: Elsevier. Retrieved August 20, 2005, from http://tecfa.unige.ch/tecfa/publicat/ dil-papers-2/Dil.7.1.10.pdf 
Dillenbourg, P. (1999). Introduction: What do you mean by "collaborative learning"? In P. Dillenbourg (Ed.), Collaborative learning: Cognitive and computational approaches (pp. 1-19). Amsterdam: Pergamon, Elsevier Science. Retrieved August 20, 2005 from http://tecfa.unige.ch/tecfa/publicat/dil-papers-2/Dil.7.1.14.pdf

Ellis, R. (2003). Task-based language learning and teaching. Oxford: Oxford University Press.

George, S. (2001). Apprentissage collectif à distance. SPLACH : un environnement informatique support d'une pédagogie de projet. Unpublished doctoral dissertation, Université du Maine, Le Mans, France

Henri, F., \& Lundgren-Cayrol, K. (2001). Apprentissage collaboratif à distance. Quebec: Presses de l'université du Québec.

Herring, S. (2004). Computer-mediated discourse analysis: An approach to researching online behavior. In S. A. Barab, R. Kling, \& J. H. Gray (Eds.), Designing for virtual communities in the service of learning (pp. 338-376). New York: Cambridge University Press.

Johnson, D. W., \& Johnson, R. (2004). Cooperation and the use of technology. In D. Jonassen (Ed.), Handbook of research on educational communications and technology (2nd ed.) (pp. 785-811). Mahwah, NJ: Lawrence Erlbaum.

Kern, R., Ware, P., \& Warschauer, M. (2004). Crossing frontiers: new directions in online pedagogy and research. Annual Review of Applied Linguistics, 24, 243-260.

Kern, R., \& Warschauer, M. (2000). Introduction: Theory and practice of network-based language teaching. In M. Warschauer \& R. Kern (Eds.), Network-based language teaching: Concepts and practice (pp.1-19). Cambridge: Cambridge University Press.

Koschmann, T. (Ed.). (1996). CSCL: Theory and practice of an emerging paradigm. Mahwah, NJ: Lawrence Erlbaum.

Lamy, M.-N., \& Goodfellow, R. (1999). 'Reflective conversation' in the virtual language classroom. Language Learning \& Technology, 2 (2), 43-61. Retrieved February 7, 2006, from http://1lt.msu.edu/vol2num2/article2

Linard, M. (2003). Autoformation, éthique et technologies: enjeux et paradoxes de l'autonomie. In B. Albero (Ed.), Autoformation et enseignement supérieur (pp. 241263). Paris: Hermès/Lavoisier.

Mangenot, F. (1996). Informatique et autonomie dans l'apprentissage des langues. In B. Rüschoff \& D. Wolff (Eds.), Technology-enhanced language learning in theory and practice, Proceedings of EUROCALL 94 (pp. 21-32). Karlsruhe: Pädagogische Hochschule Karlsruhe.

Mangenot, F. (2003). Tâches et coopération dans deux dispositifs universitaires de formation à distance. ALSIC (Apprentissage des langues et systèmes d'information et de communication), 6 (1), 109-125. Retrieved February 7, 2006, from http://al sic.org

Nissen, E. (2003). Apprendre une langue en ligne dans une perspective actionnelle. Effets de l'interaction sociale. Unpublished doctoral dissertation, Université Louis Pasteur, Strasbourg, France.

Nissen, E. (2005). Autonomie du groupe restreint et performance. ALSIC (Apprentissage des langues et systèmes d'information et de communication), 8 (1), 19-34. Re- 
trieved February 17, 2006, from http://alsic.org

Paulus, T. M. (2005). Collaborative and cooperative approaches to online group work: The impact of task type. Distance Education, 26 (1), 111-125.

Peraya, D., \& Dumont, P. (2003). Interagir dans une classe virtuelle: analyse des interactions verbales médiatisées dans un environnement synchrone. Revue française de pédagogie, $n^{\circ} 145,51-61$.

Pléty, P. (1998). Comment apprendre et se former en groupe. Paris: Retz.

Sinclair, J., \& Coulthard, M. (1975). Towards an analysis of discourse: The English used by teachers and pupils. Oxford: Oxford University Press.

Roschelle, J., \& Teasley, S. D. (1995) Construction of shared knowledge in collaborative problem solving. In C. O'Malley (Ed.), Computer supported collaborative learning (pp. 69-97). Berlin, New York: Springer Verlag. Retrieved on August 20, 2005, from ctl.sri.com/publications/ downloads/JointProblemSpace.pdf

Warschauer, M., \& Kern, R. (Eds.). (2000). Network-based Language Teaching: Concepts and practice. Cambridge: Cambridge University Press.

\section{AUTHORS' BIODATA}

François Mangenot, Professor at Stendhal University in Grenoble, is a specialist in CALL and technology-enhanced distance learning. He is a member of Lidilem (laboratoire de linguistique et didactique des langues étrangères et maternelle), where he leads an international research program called ODIL (outils et didactique pour les interactions en ligne).

Elke Nissen, Lecturer at Stendhal University in Grenoble, focuses her research on CALL, Internet-based teaching and learning and e-learning. She is a member of Lidilem and involved in the ODIL research program.

\section{AUTHORS' ADDRESSES}

François Mangenot

Université Stendhal - Grenoble 3

BP 25

38040 Grenoble Cedex 9

France

Phone: +33476826800

Fax: $\quad+33476824395$

Email: fmangenot@infonie.fr

Elke Nissen

Université Stendhal - Grenoble 3

BP 25

38040 Grenoble Cedex 9

France

Phone: +33476824300

Fax: $\quad+33476824185$

Email: elke.nissen@u-grenoble3.fr 
